\title{
ANALISIS SEKUENS DAN FILOGENETIK BEBERAPA TUMBUHAN Syzygium (MYRTACEAE) DI SULAWESI UTARA BERDASARKAN GEN matK
}

\author{
Presticilla D. Irawan ${ }^{1)}$ Trina E. Tallei ${ }^{1)}$ Beivy J. Kolondam ${ }^{1)}$ \\ ${ }^{1)}$ Program Studi Biologi, Fakultas MIPA, Universitas Sam Ratulangi \\ Jl. Kampus UNSRAT FMIPA, Manado 95115 \\ e-mail: presticilla@ymail.com; trina_tallei@unsrat.ac.id; beivy.kolondam@unsrat.ac.id
}

\begin{abstract}
ABSTRAK
Syzygium (Myrtaceae) merupakan tumbuhan yang memiliki banyak manfaat di bidang ekonomi dan kesehatan. Informasi dan publikasi mengenai klasifikasi tumbuhan Syzygium masih sedikit. Pengelompokkan beberapa jenis tumbuhan dalam genus ini masih ditemui masalah, antara lain tumpang tindihnya nama Syzygium dengan Eugenia dan beberapa tumbuhan belum diketahui posisinya dalam klasifikasi. Penelitian ini bertujuan untuk menganalisis variasi sekuens gen matK dan mengkonstruksi pohon filogenetik pada beberapa tumbuhan Syzygium di Sulawesi Utara, yaitu pakoba, jamblang dan bombongan. Analisis variasi sekuens menunjukkan adanya perbedaan satu nukleotida antara tumbuhan pakoba dan jamblang, serta perbedaan 5-6 nukleotida antara bombongan dengan jamblang dan pakoba. Selain itu, variasi juga ditunjukan antara sekuens sampel tumbuhan Syzygium dengan sekuens kerabat yang diperoleh dari basis data GenBank yaitu adanya perbedaan 2-3 nukleotida dengan spesies kerabat terdekat dan perbedaan 5-6 nukleotida dengan spesies kerabat terjauh. Hasil perhitungan jarak genetik menggunakan Kimura-2parameter menunjukkan nilai jarak interspesies kecil, yaitu 0.000-0.011.
\end{abstract}

Kata Kunci: Variasi Genetik, Gen matK, Syzygium, Sulawesi Utara.

\section{SEQUENCES AND PHYLOGENETIC ANALYSIS OF Syzygium (MYRTACEAE) PLANTS IN NORTH SULAWESI BASED ON matK GENE}

\begin{abstract}
Syzygium (family: Myrtaceae) is a genus of plants with many benefits in economics and health. Information and publications on the classification of Syzygium are still few in number. Grouping several plant species in this genus is still problematic, among other there is overlapping of Syzygium and Eugenia and the position in the classification of some plants are yet unknown. This study was conducted to analyze the sequences variations of matK genes and and to construct phylogenetic tree of some Syzygium plants found in North Sulawesi, namely pakoba, jamblang and bombongan. There are one nucleotide nucleotide difference between pakoba and jamblang, as well as 5-6 nucleotide differences between bombongan with jamblang and pakoba. In addition, 23 sequence variations also occur between our Syzygium samples and their closest allied species and 5-6 nucleotides differences with their farthest allied species, all of which are retrieved from GenBank. Genetic distance calculated using Kimura-2-parameter shows a very low (0.000-0.011) interspesific distance.
\end{abstract}

Keywords: Genetic Variation, matK Gene, Syzygium, Sulawesi Utara.

\section{PENDAHULUAN}

Syzygium salah satu genus dari suku Myrtaceae (jambu-jambuan), memiliki lebih dari 1000 spesies, dan merupakan tumbuhan utama flora hutan hujan tropis di daerah Malesia (Asif et al., 2013). Di Indonesia, jumlah tumbuhan Syzygium mencapai 300 jenis, dan di Jawa terdapat sekitar 60 jenis
(Sunarti, 2015). Banyak anggota dari genus ini memiliki nilai ekonomis dan telah digunakan sebagai obat-obatan, makanan, bahan bangunan, dan tanaman hias. Syzygium merupakan genus yang sulit untuk diklasifikasikan karena hanya memiliki sedikit karakter morfologi yang secara konsisten menghubungkan suatu spesies ke dalam kelompok spesies tertentu. Hal ini juga 
didukung dengan tumpang tindihnya nama Syzygium dengan Eugenia. Hingga saat ini hanya relatif sedikit publikasi mengenai klasifikasi Syzygium (Craven dan Biffin, 2010).

Identifikasi spesies secara akurat menggunakan metode tradisional bisa memakan waktu yang lama disebabkan kurangnya pengetahuan mengenai tumbuhan dan/atau kurangnya karakter bunga dan buah yang dibutuhkan untuk identifikasi (Colpaert et al., 2005). Identifikasi spesies berbasis sekuens DNA merupakan metode yang dianggap cepat, dapat dipertanggungjawabkan, dan konsisten, sehingga penting dalam penelitian biologi konservasi dan keanekaragaman (Waugh, 2007). Identifikasi dengan sekuens DNA dilakukan menggunakan penanda molekuler. Salah satu penanda molekuler yang saat ini digunakan dalam mengungkapkan taksonomi yaitu kode batang DNA (DNA barcoding) yang merupakan urutan sekuen pendek DNA yang dapat menunjukkan variasi genetik dalam suatu spesies (Chippindale et al., 1999). Dalam proses DNA Barcoding, gen tertentu dapat digunakan sebagai marker dalam pembagian genetik spesies dan rekonstruksi filogenetik. Salah satu gen yang digunakan yaitu matK (Maturase K), yang merupakan gen kloroplas berukuran sekitar 1500 pasang basa (bp) yang berlokasi di intron trnK (Selvaraj et al., 2008; Jethra et $a l ., 2014)$. Saat ini gen matK telah digunakan sebagai alat yang penting untuk memeriksa keanekaragaman genetik intraspesies dan interspesies karena memiliki laju substitusi yang tinggi (Hollingsworth et al., 2011). Penelitian ini dilakukan dengan tujuan menganalisis variasi sekuens gen matK dan membangun pohon filogenetik beberapa jenis Syzygium yang ada di Sulawesi Utara, yaitu pakoba, jamblang, dan bombongan.

\section{METODE PENELITIAN}

\section{Ekstraksi DNA}

Ekstraksi DNA menggunakan Axyprep Multisource Genomic DNA miniprep kit (Axygen). Modifikasi dilakukan untuk memaksimalkan lisis dengan waktu inkubasi 1 jam dalam suhu $60^{\circ} \mathrm{C}$ (Kolondam et al., 2013). Bagian sampel yang digunakan dalam ekstraksi yaitu potongan kecil lembaran daun muda.

\section{Amplifikasi Gen matK dengan metode PCR dan Sekuensing}

Primer gen matK yang digunakan yaitu matK-3F-R (5'-CGT ACA GTA CTT TTG TGT TTA CGA G-3') dan matK-1R-F (5'ACC CAG TCC ATC TGG AAA TCT TGG TTC-3') yang dirancang oleh Ki-Joong Kim (Kuzmina et al., 2012). Amplifikasi gen matK dilakukan di dalam $40 \mu \mathrm{L}$ reaksi PCR menggunakan 2x KapaTaq PCR MasterMix. Komponen yang dicampur yaitu $20 \mu \mathrm{L} 2 \mathrm{X}$ KapaTaq, $1,5 \mu \mathrm{L}$ primer forward, $1,5 \mu \mathrm{L}$ primer reverse, $2 \mu \mathrm{L}$ templat DNA, dan $15 \mu \mathrm{L}$ $\mathrm{ddH}_{2} \mathrm{O}$ (air terdeionisasi) untuk satu kali reaksi. Pengaturan suhu untuk mesin PCR TPersonal (Bimetra) dimulai dengan denaturasi awal (initial denaturation) pada $95^{\circ} \mathrm{C}$ selama 2 menit, 35 siklus yang terdiri atas tahap denaturasi, penempelan primer pada cetakan, dan ekstensi DNA. Suhu dan waktu berturut-turut yaitu $95^{\circ} \mathrm{C}$ selama 30 detik, $50^{\circ} \mathrm{C}$ selama 30 detik, dan $72^{\circ} \mathrm{C}$ selama 50 detik (Tallei et al., 2016). Sekuensing dilakukan oleh penyedia jasa sekuensing $I^{s t}$ BASE Malaysia.

\section{Analisis Data}

Data sekuens dirakit dan diedit menggunakan Genious v 5.6 mengikuti prosedur Tallei dan Kolondam (2015). Proses pairwise alignment dilakukan untuk hasil sekuensing menggunakan primer reverse (matK-1R-f), kemudian dipadukan dengan hasil sekuensing primer forward (matK-3F-r) menggunakan Global Alignment yang terintegrasi dalam Geneious. Kedua ujung sekuens dipotong pada saat penjajaran untuk menghindari salah pembacaan sehingga semua sekuens dipotong hingga menyisakan 648 nukleotida. Sekuens matK dari sampel digunakan untuk mencari sekuens serupa di Basic Local Alignment Search Tool (BLAST) (http://blast.ncbi.nlm.nih.gov/Blast.cgi).

Sekuens-sekuens matK kemudian dijajarkan menggunakan Multalin v.5.4.1 (multalin.toulouse.inra.fr/multalin/). Pohon filogenetik dikonstruksi menggunakan metode UPGMA dan jarak genetik dihitung menggunakan metode Kimura's 2-parameter yang terintegrasi di dalam piranti lunak MEGA6 yang dikembangkan oleh Tamura et al. (2013). 


\section{HASIL DAN PEMBAHASAN}

Penjajaran awal dilakukan antara sekuens pakoba, jamblang, dan bombongan. Hasil pada Gambar 1 menunjukkan perbedaan hanya satu nukleotida antara pakoba dan jamblang, yaitu pada posisi ke523. Perbedaan nukleotida antara bombongan dengan pakoba yaitu sebanyak 6 nukleotida, yaitu pada posisi ke- 131, 432, 474, 523, 645, dan 666. Perbedaan nukleotida bombongan dengan jamblang yaitu 5 nukleotida, yaitu pada posisi ke- 131, 432, 474, 645, dan 666.

Masing-masing sekuens sampel yang telah diedit menggunakan Geneious digunakan dalam pencarian sekuens kerabat terdekatnya di GenBank (Gambar 2). Dilihat dari perbedaan jumlah variasi nukleotida, spesies yang mendekati kelima sampel tersebut yaitu Syzygium ngoyense dan Syzygium sandwicense. Perbedaan dua nukleotida terdapat antara Syzygium ngoyense dengan jamblang (posisi 77, 612), serta berbeda tiga nukleotida dengan pakoba (posisi 77, 469, 612) dan bombongan (posisi 378, 420, 591). Syzygium sandwicense berbeda dua nukleotida dengan sekuens jamblang (posisi 77, 612), serta berbeda tiga nukleotida dengan sekuens pakoba (posisi 77, 469,612 ) dan bombongan (posisi 378, 420, 591). Spesies kerabat terjauh dengan ketiga sampel yaitu Syzygium glenum, di mana perbedaan sekuens dengan jamblang 5 nukleotida (posisi 77, 387, 416, 612, 613), serta dengan pakoba (posisi 77, 387, 416, $469,612,613$ ) dan bombongan (posisi 378 , $387,416,420,591,613$ ) yaitu 6 nukleotida. Hasil penjajaran sekuens jamblang dengan beberapa sekuens Syzygium cumini di GenBank (DQ088575, JX495762, GU134997, AB924857, AB924961, AB925017, AB925174, AB925241, AB925007, AB 925038, GU135062, JN 114772) menunjukkan perbedaan 4-10 nukleotida (Gambar 3).

Hasil sekuens dibuat dalam format FASTA untuk konstruksi pohon filogenetik menggunakan MEGA6. Pohon dikonstruksi dengan model UPGMA dan jarak genetik Kimura-2-Parameter. Pada proses pembuatan pohon tersebut, sekuens tumbuhan Myrtaceae lain yaitu Psidium guajava (AB354958) digunakan sebagai outgroup. Selain itu sekuens Eugenia, yaitu Eugenia capensis (KF147400), Eugenia salamensis (JQ588488), dan Eugenia nesiotica (GQ981989) digunakan untuk memperjelas hubungan dengan Syzygium karena penamaan dengan keduanya yang tumpang tindih (Craven dan Biffin, 2010). Pohon tersebut menunjukkan posisi sampel dengan spesies kerabatnya (Gambar 4). Posisi jamblang dengan pakoba dalam pohon filogenetik terletak pada satu klaster, sehingga menunjukkan bahwa keduanya berkerabat dekat. Akan tetapi, posisi Syzygium cumini (DQ088575) berada pada klaster yang berbeda, sehingga jamblang tampaknya memiliki kekerabatan yang jauh dari $S$. Cumini tersebut. Pohon filogenetik mengindikasikan hubungan yang jauh antara Eugenia dengan Syzygium.

Jarak genetik antara sampel tumbuhan dengan kerabat Syzygium dihitung menggunakan metode Kimura-2-Parameter pada MEGA6 (Kimura, 1980). Hasil menunjukkan jarak genetik antara pakoba dan jamblang yaitu 0.002. Menurut Tallei et al. (2016), semakin sedikit nilai jarak genetik antara dua organisme, semakin dekat pula hubungan kekerabatan keduanya. Hasil tersebut menandakan bahwa kemungkinan besar tumbuhan pakoba dan jamblang berkerabat dekat, dan bahkan cenderung sebagai spesies yang sama atau merupakan subspesies. Jarak genetik antara jamblang dengan Syzygium cumini yaitu 0.010. Nilai ini jauh lebih besar dibandingkan nilai antara pakoba dan jamblang. Nilai jarak genetik antara bombongan dengan Syzygium lainnya yang diperoleh dari GenBank berkisar antara 0.005-0.010. Nilai jarak interspesies di antara genus Syzygium yaitu 0.000-0.011. Kisaran tersebut sangat kecil dibandingkan dengan hasil jarak genetik interspesies 0.0023-0.0291 untuk tumbuhan Acacia (Newmaster dan Ragupathy, 2009), rata-rata jarak genetik interspesies $0.042 \pm 0.0030$ untuk tumbuhan dari famili Myristicaceae (Newmaster et al., 2008), serta rata-rata jarak genetik interspesies $0.0093 \pm 0.0081$ untuk tumbuhan Rosaceae (Pang et al., 2010). Berdasarkan hasil tersebut, kemampuan gen matK untuk memisahkan tumbuhan Syzygium dalam hal ini rendah. 


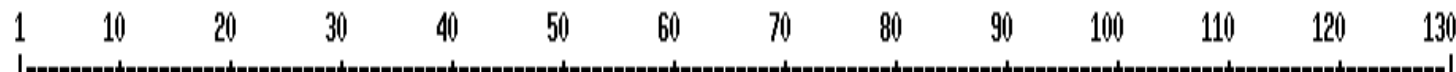

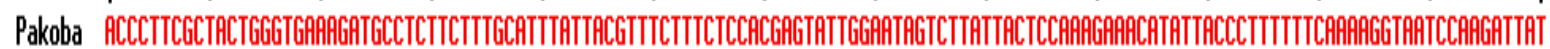

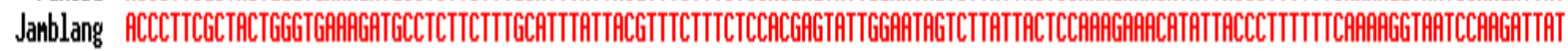

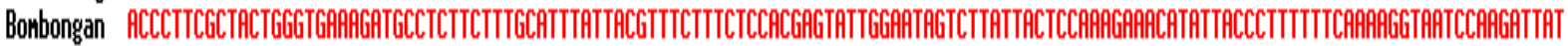

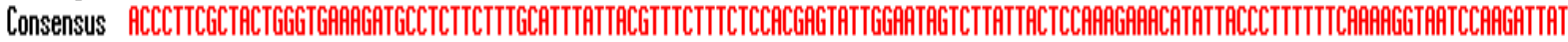

Pakoba

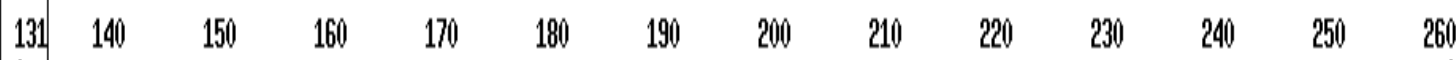

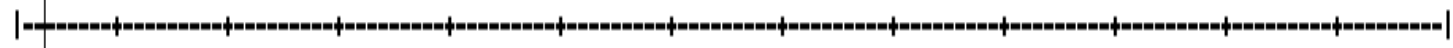

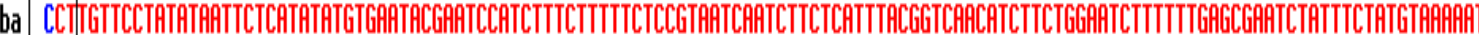

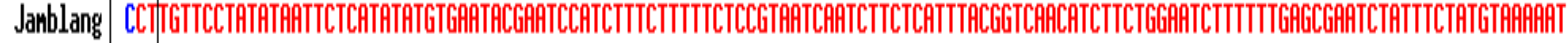

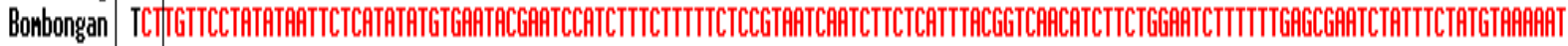

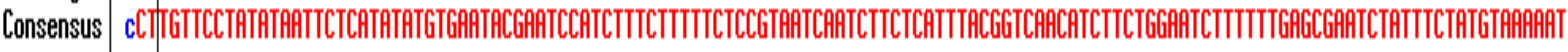

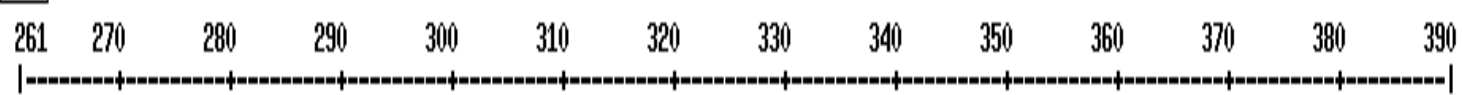

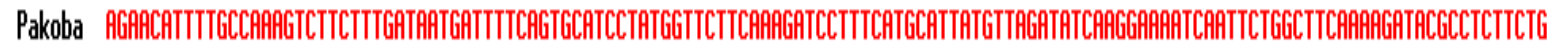

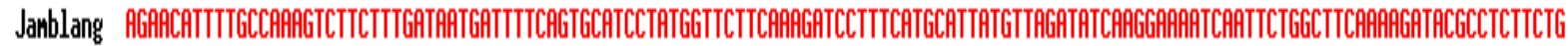

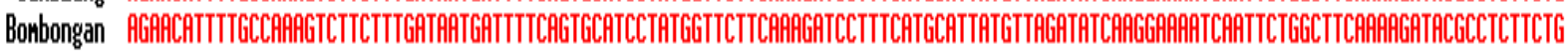

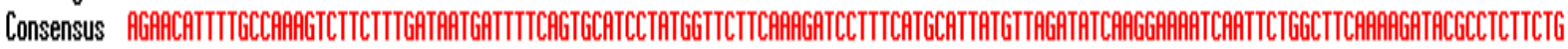

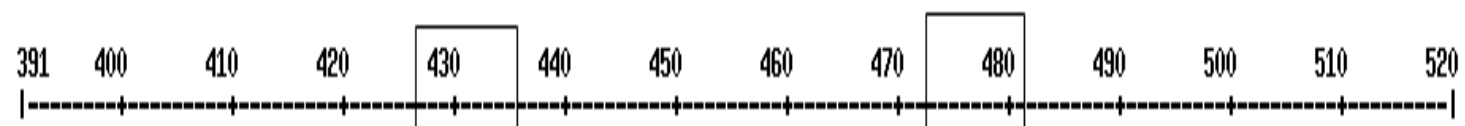

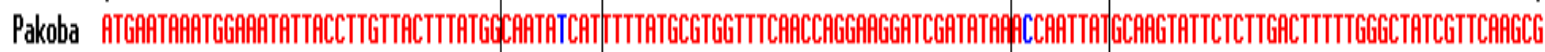

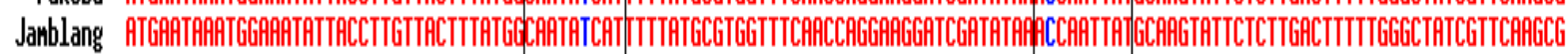

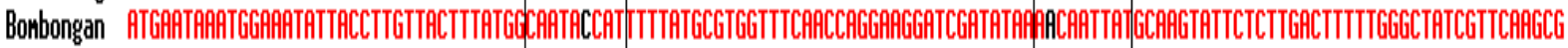

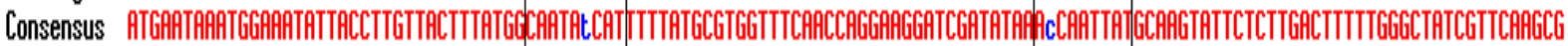

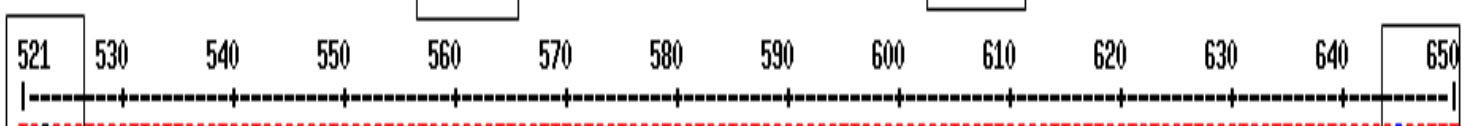

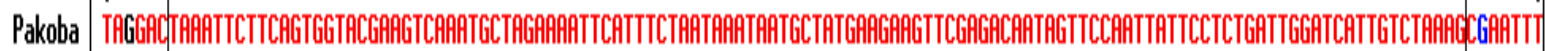

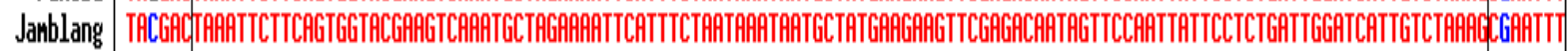

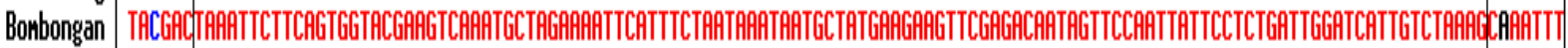

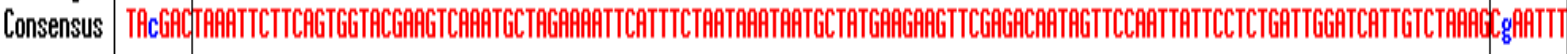

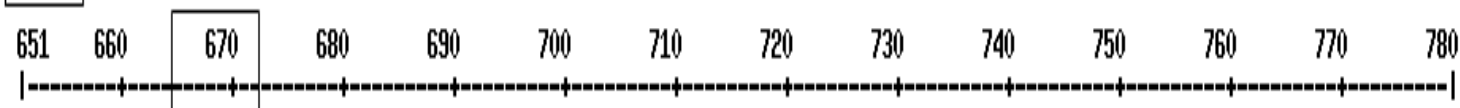

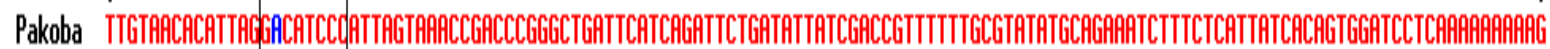

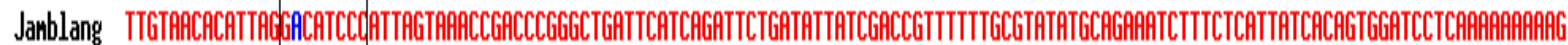

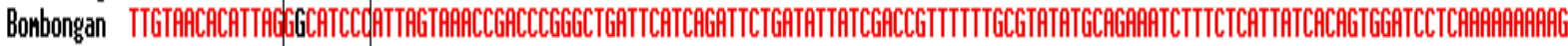

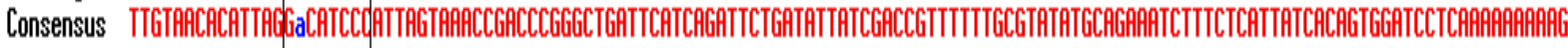

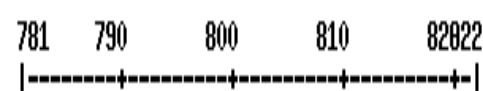

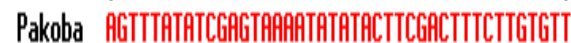

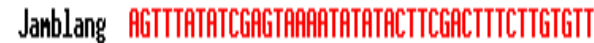

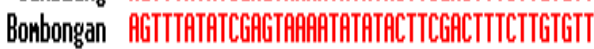

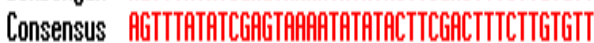

Gambar 1. Penjajaran sekuens gen matK tumbuhan Syzygium di Sulawesi Utara, yaitu pakoba, jamblang, dan bombongan menggunakan software Multalin v5.4.1. 


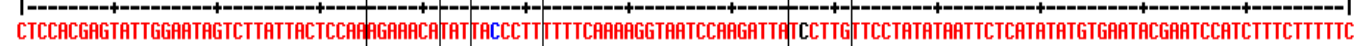

Pakoba

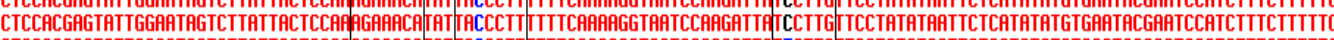

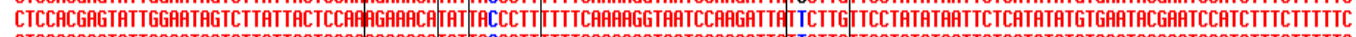

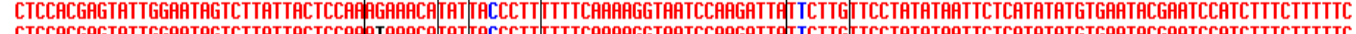

yzygiun Syzygiun_naci Syzygiun_sanarangens

Syzygiun_aqueur

Syzion

Syzygiun_tierneyanun

Bonbongan

Syzygiun_australe

Syzygiun_erythrocaly

Syzygiun_fibrosun

Syzygiun_glenu

Consensus

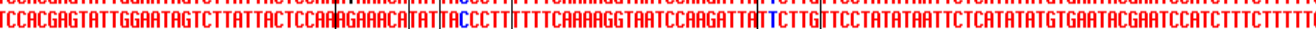

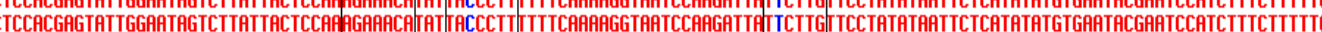
cTCCACG

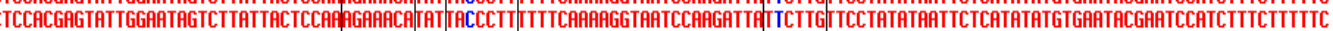

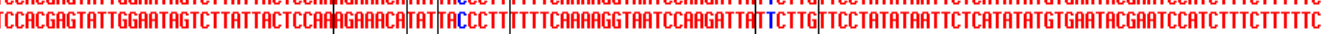

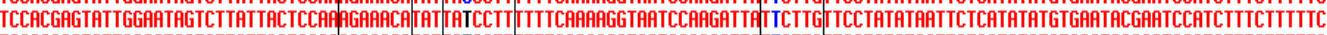

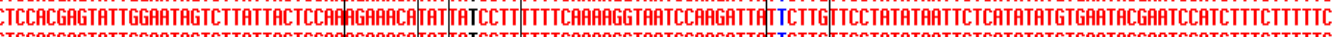

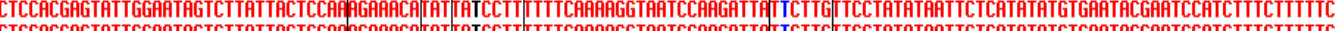

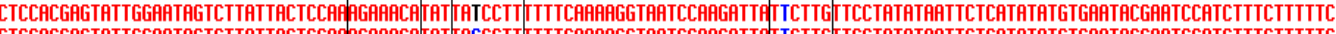

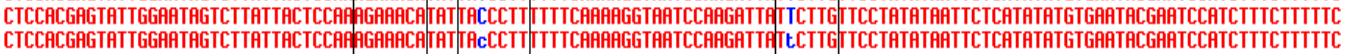
$131 \quad 140$
150
160
$170 \quad 180$
190
200
210
220
230
240
$250 \quad 260$

Pakoba

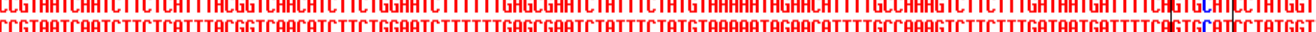

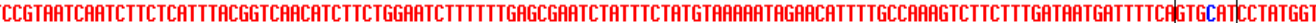

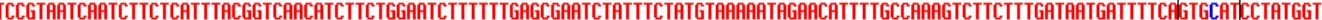

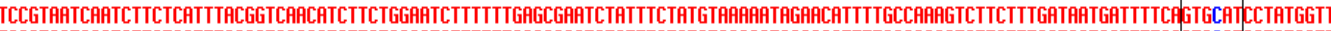

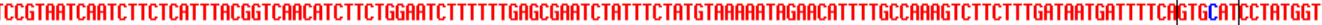

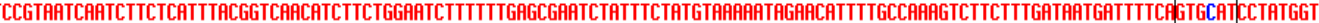

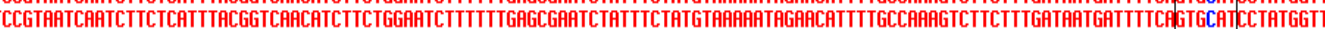

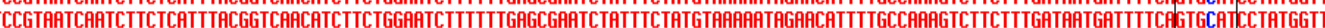

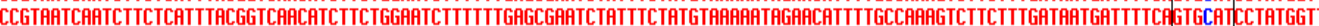

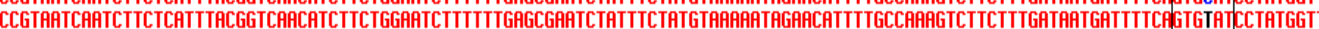

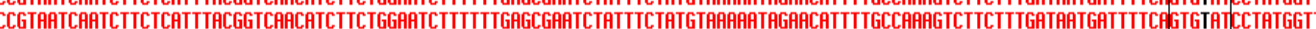

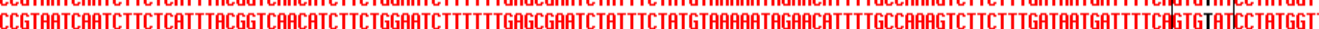
TCGT

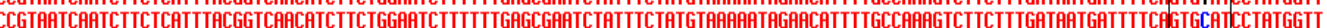

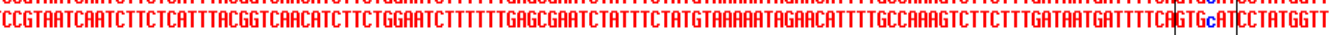

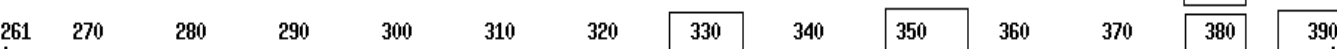

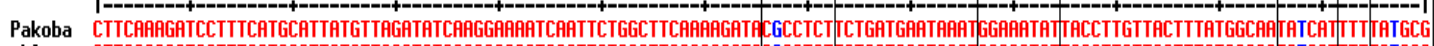

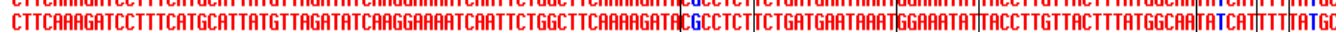

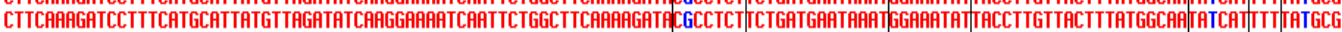

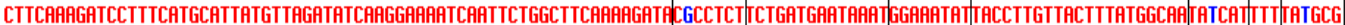

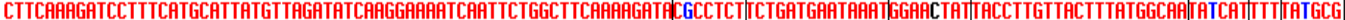

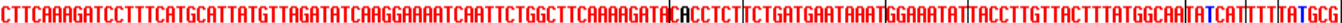

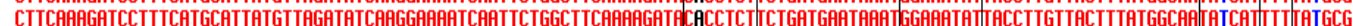

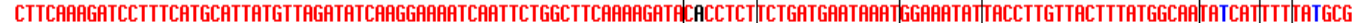
CTTCA CTTCя

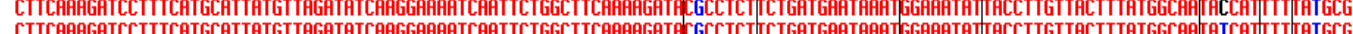

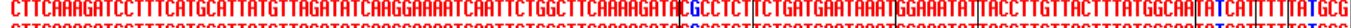

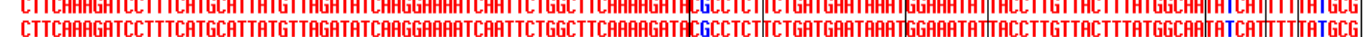

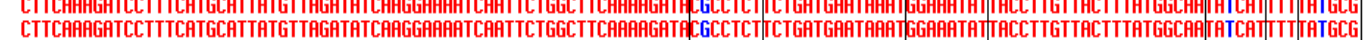

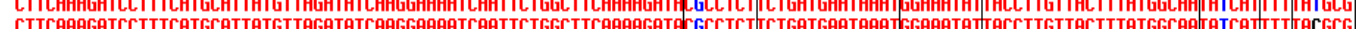

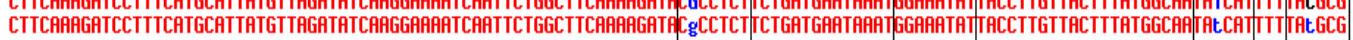
\begin{tabular}{llllllllllllll|}
391 & 400 & 410 & 420 & 430 & 440 & 450 & 460 & 470 & 480 & 490 & 500 & 510 & 520
\end{tabular}

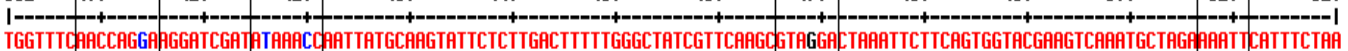

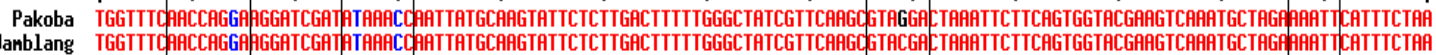

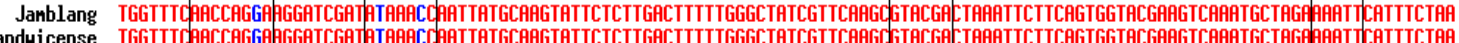

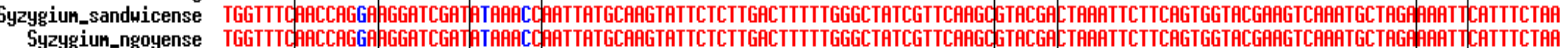

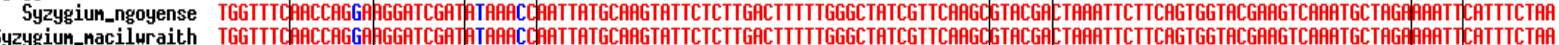

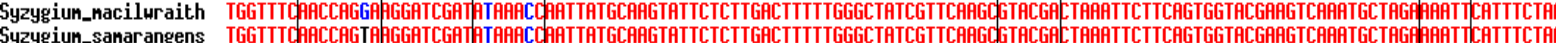

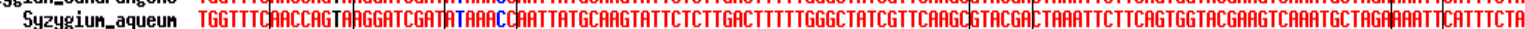

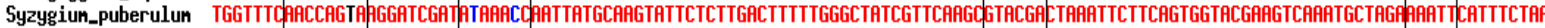

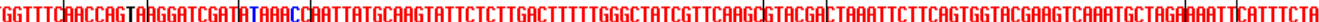

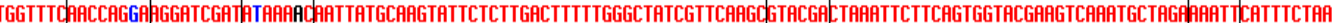

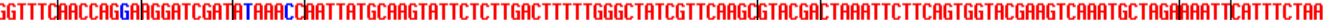

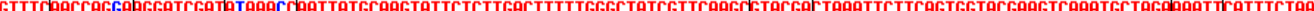
TGGTTC

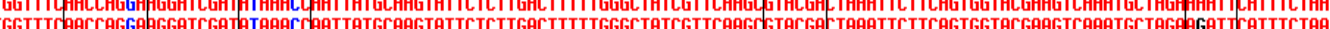
TCGTTTCRCCACCACCATCCAT

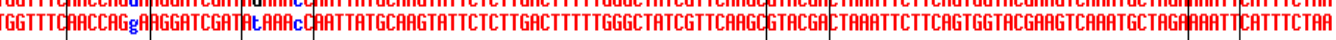

$$
\begin{array}{lllllllllll}
521 & 530 & 540 & 550 & 560 & 570 & 580 & 590 & 600 & 610 & 620
\end{array}
$$

Pakoba

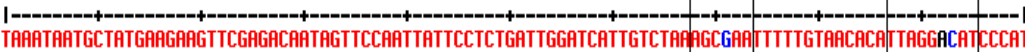

Janblang

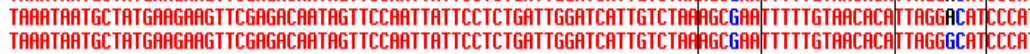

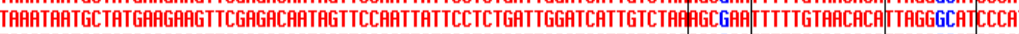

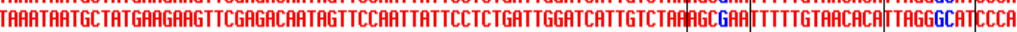

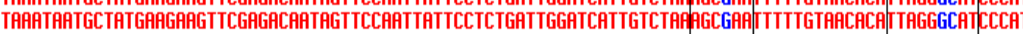

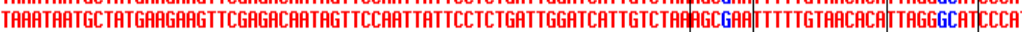

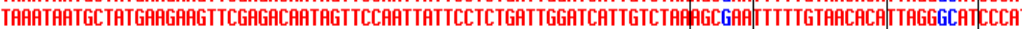

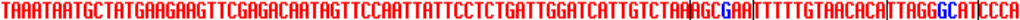

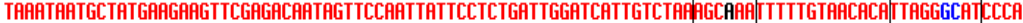

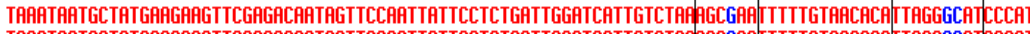

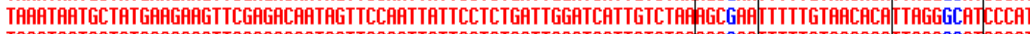

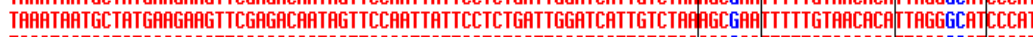

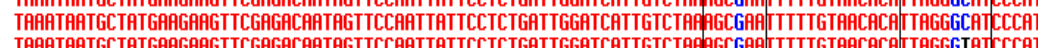

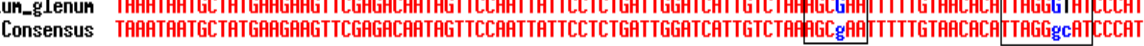

Gambar 2. Penjajaran sekuens gen matK tumbuhan Syzygium di Sulawesi Utara dengan kerabat terdekat dari genus Syzygium yang diperoleh dari GenBank 
10

$20 \quad 30$

40

50

60

70

80

90

$100 \quad 110$

120

130

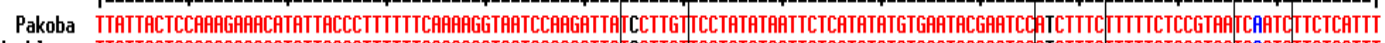

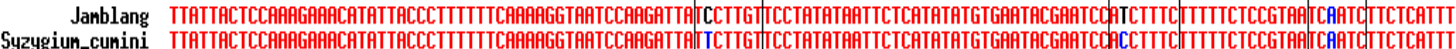

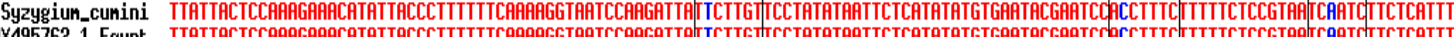

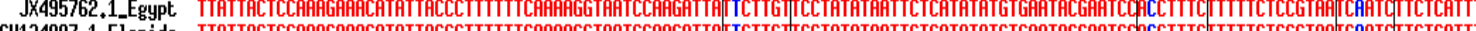
GU134957__orida AB924857.1_Canbodia AB924961.1_Canbodia AB925017.1_Canbodia AB925174,1_Canbodia AB925241.1_Canbodia AB925007.1_Canbodia GU135062 1 Florida

JN114772.1_India

Consensus

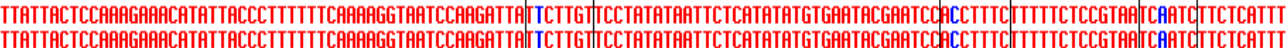

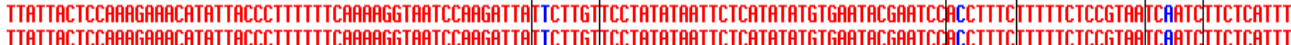
TTятTACTCC

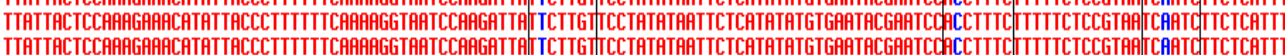
ITATTACTCC

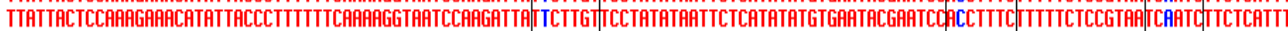

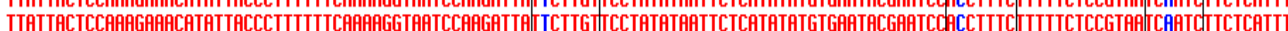

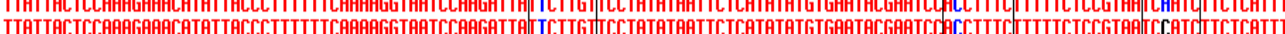
ТтЯтTACTCC

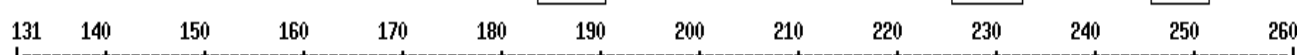

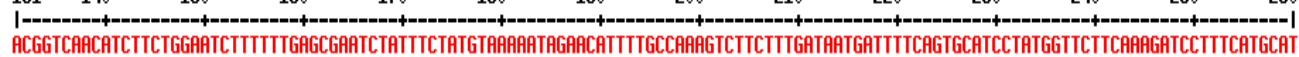

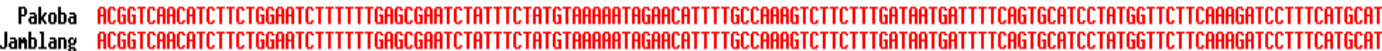

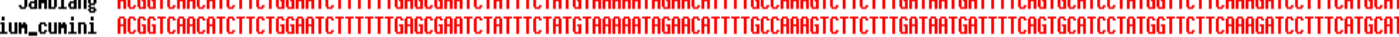

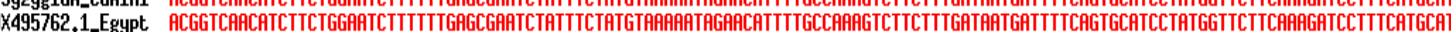

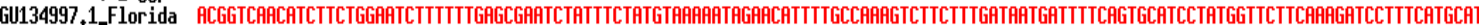
8в924857.1

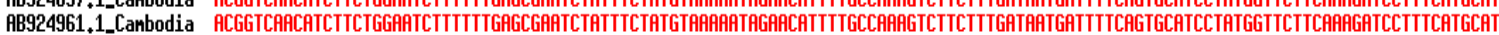

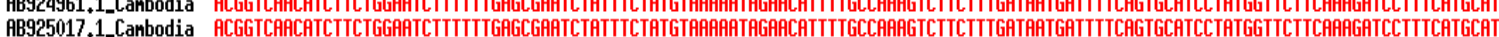
AB925174.1_Canodia AB925241.1_anodia ACG AB925007__Canodia ACGG

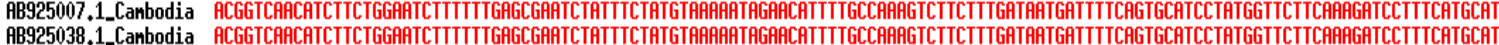

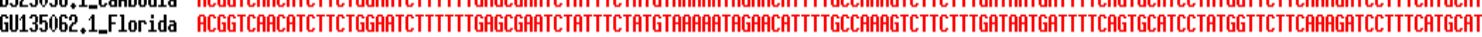

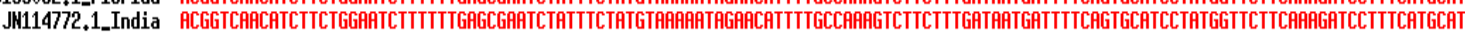

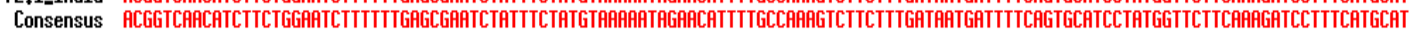

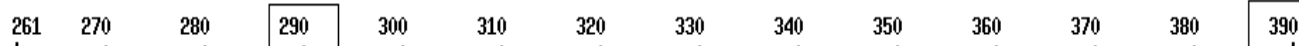

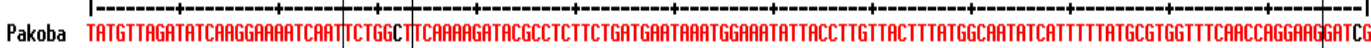

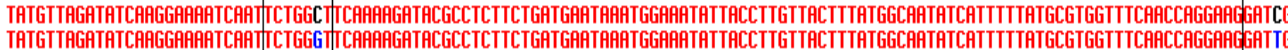

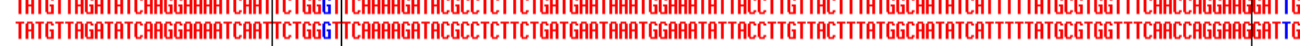
TATGtTAG

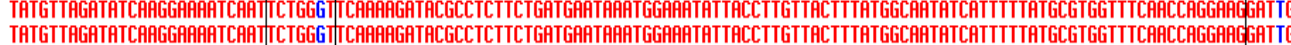

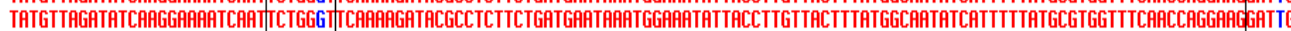

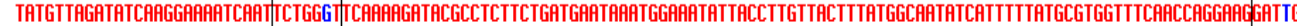

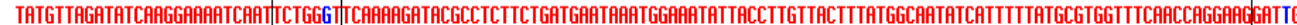

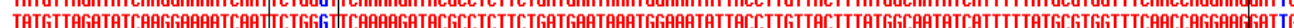

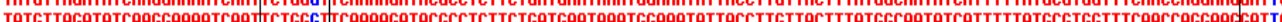
TAT TिT The

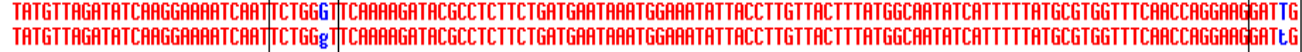

$\begin{array}{lllllllllllll}391 & 400 & 410 & 420 & 430 & 440 & 450 & 460 & 470 & 480 & 490 & 500 & 510\end{array}$

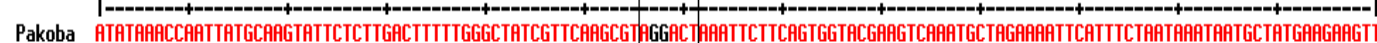

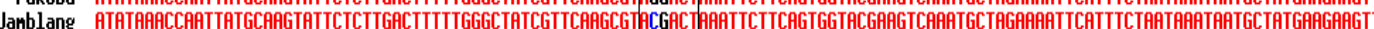

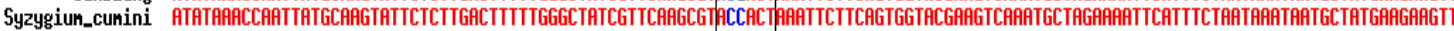

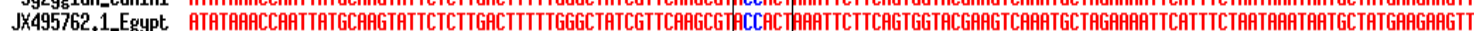

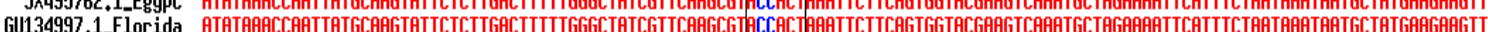
(1) A

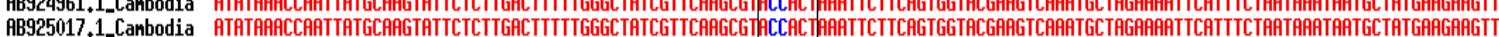

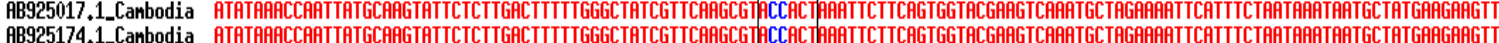

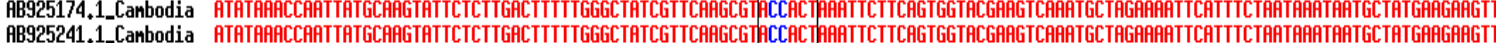

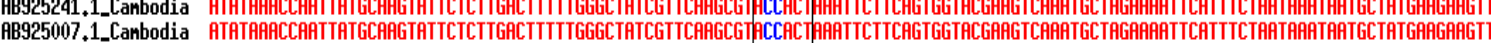

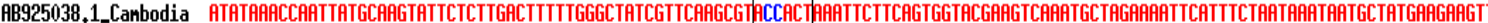

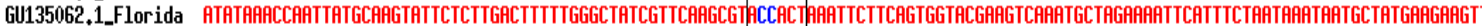

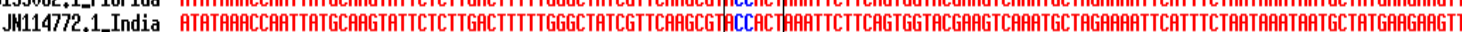

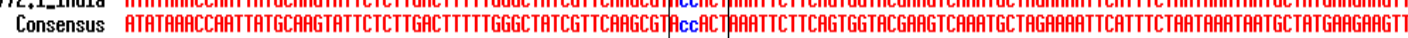
$\begin{array}{lllllllllllllll}521 & 530 & 540 & 550 & 560 & 570 & 580 & 590 & 600 & 610 & 620 & 630 & 640 & 650\end{array}$

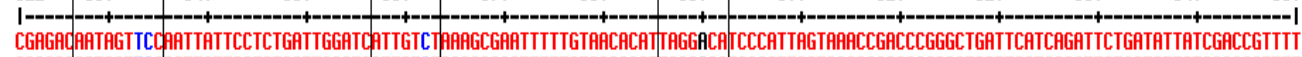

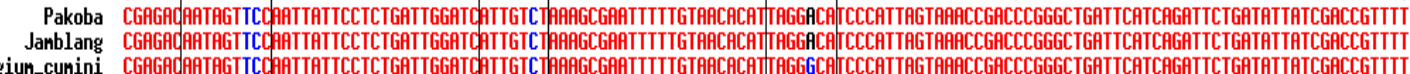

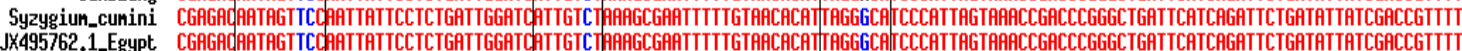

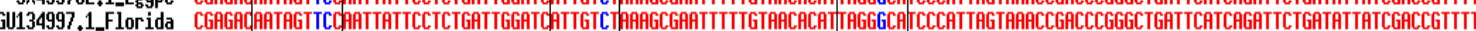

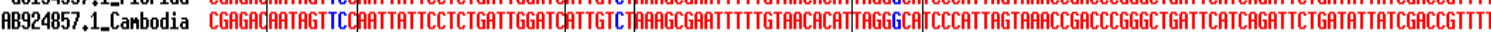

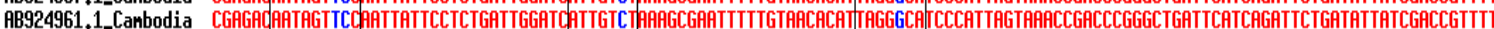
AB925017

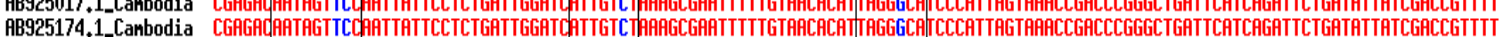

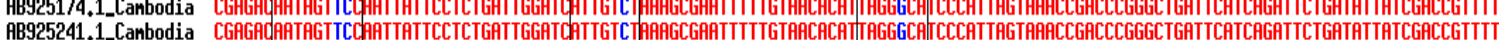
AB925007.1_Canbodia CGAG

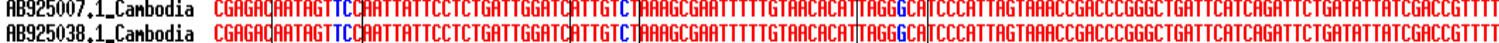

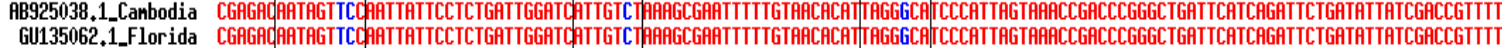

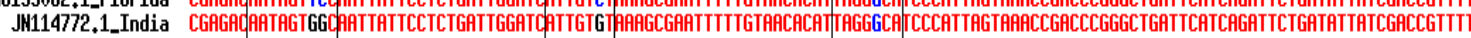

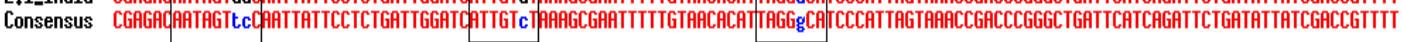

Gambar 3. Penjajaran sekuens gen matK tumbuhan jamblang dengan sekuens Syzygium cumini yang diperoleh dari GenBank 


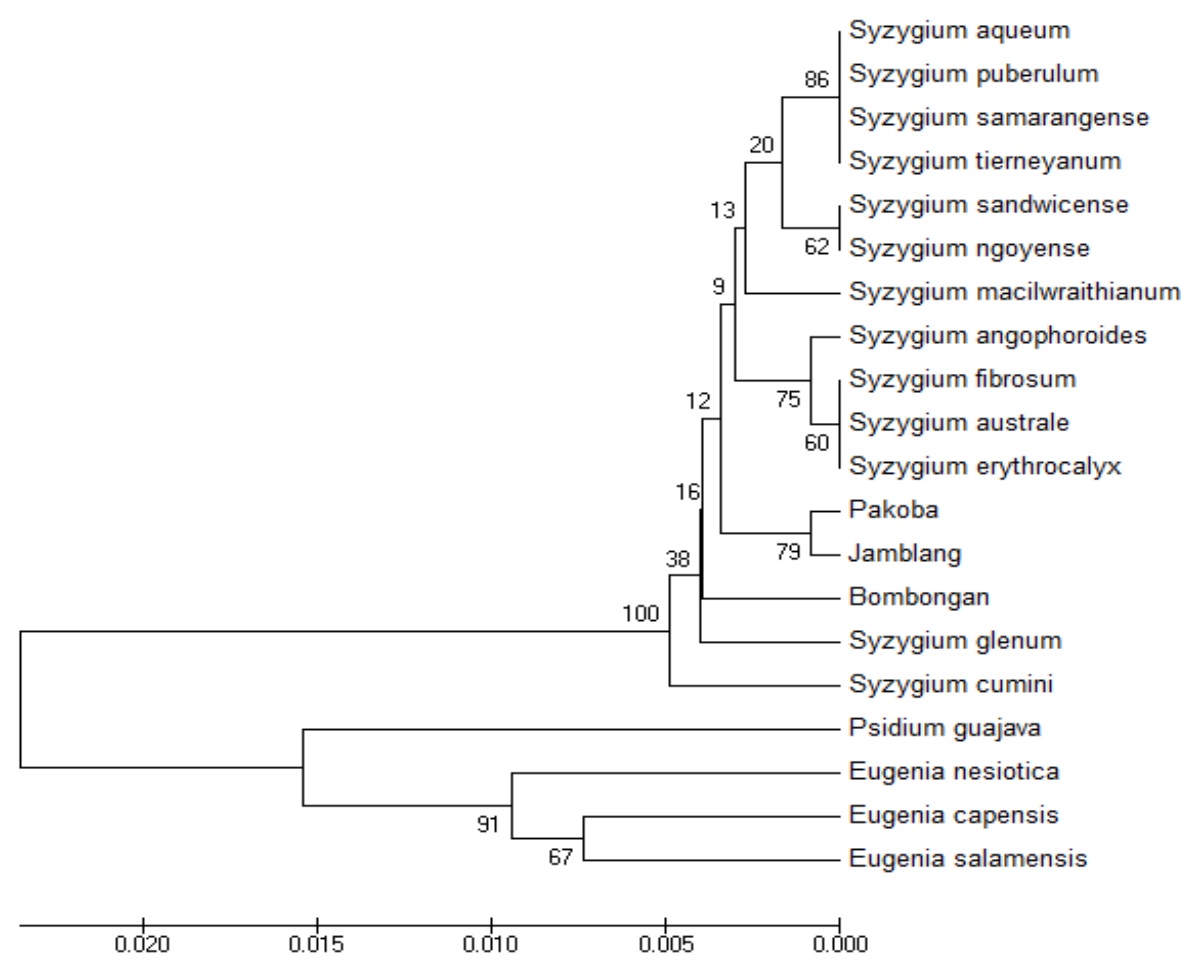

Gambar 4. Pohon Filogenetik Syzygium yang dikonstruksi menggunakan metode UPGMA dalam software MEGA6

\section{KESIMPULAN}

Perbandingan variasi genetik matK sampel menunjukkan perbedaan hanya 1 nukleotida antara jamblang dan pakoba, serta perbedaan 5-6 nukleotida antara keduanya dengan bombongan. Perbedaan nukleotida sekuens sampel dengan kerabatnya di GenBank yaitu 2-6 nukleotida. Nilai jarak genetik interspesies Syzygium termasuk rendah, yaitu 0.000-0.011.

\section{DAFTAR PUSTAKA}

Asif, H., Khan, A., Iqbal, A., Khan, I.A., Heinze, B. 2013. The chloroplast genome sequence of Syzygium cumini (L.) and its relationship with other angiosperms. Tree Genetics \& Genomes 9(3): 867-877.

Chippindale, P.T., Dave, V.K., Whitmore, D.H., Robinson, J.V. 1999 Phylogenetic relationships of North American damselflies of the genus Ischnura (Odonata: Zygoptera: Coenagrionidae) based on sequences of three mitochondrial genes.
Molecular Phylogenetics and Evolution 11(1): 110-121.

Colpaert, N., Cavers, S., Bandou, E., Caron, H., Gheysen, G., Lowe, A.J. 2005. Sampling Tissue for DNA Analysis of Trees: Trunk Cambium as an Alternative to Canopy Leaves. Silvae Genetica 54(6): 265-269.

Craven, L.A., Biffin, E. 2010. An infrageneric classification of Syzygium (Myrtaceae). Blumea 55(1): 94-99.

Hollingsworth, P.M., Graham, S.W., Little, D.P. 2011. Choosing and Using a Plant DNA Barcode. PLOS ONE 6(5): e19254.

Kolondam, B. J. 2015. Applying matK Gene For Identification of Liliopsida Plant Species From North Sulawesi Through Bold Systems. International Journal of Applied Biology and Pharmaceutical Technology 6(2): 242-245. 
Kolondam, B.J., Lengkong, E., PoliiMandang, J., Runtunuwu, S., Pinaria, A. 2013. Barcode DNA Anthurium Gelombang Cinta (Anthurium plowmanii) berdasarkan gen rbcL dan matK. BIOSLOGOS 3(1): 17-25.

Kuzmina, M.L., Johnson, K.L., Barron, H.R., Herbert, P.D.N., 2012. Identification of vascular plants of Churchill, Manitoba, using a DNA barcode library. BMC Ecology 12 (1):1-11. DOI:10.1186/1472-6785-12-25

Pang, X., Song, J., Zhu, Y., Xu, H., Huang, L., Chen, S. 2010. Applying plant DNA barcodes for Rosaceae species identification. Cladistics 27(2): 165170.

Newmaster, S.G., Fazekas, A.J., Steeves, A.D., Janovec, J. 2008. Testing candidate plant barcodes regions in the Myristicaceae. Molecular Ecology Resources 8(3): 480-490.

Newmaster, S.G., Ragupathy, S. 2009. Testing plant barcoding in a sister species complex of pantropical Acacia (Mimosoideae, Fabaceae). Molecular Ecology Resources 9 Suppl s1: 172-180.

Sunarti, S. 2015. Persebaran Syzygium endemik Jawa. Prosiding Seminar Nasional Masyarakat Biodiversitas Indonesia 1(5): 1093-1098.

Tallei, T.E., Kolondam, B.J. 2015. DNA Barcoding of Sangihe Nutmeg (Myristica fragrans) using matK Gene. HAYATI Journal of Biosciences 22(1): 41-47.

Tallei, T.E., Rembet, R.E., Pelealu, J.J., Kolondam, B.J. 2016. Sequence Variation and Phylogenetic Analysis of Sansevieria trifasciata (Asparagaceae). Bioscience Research 13(1): 01-07.
Tamura, K., Stecher, G., Peterson, D., Filipski, A., Kumar, S. 2013. MEGA6: Molecular Evolutionary Genetics Analysis Version 6.0. Molecular Biologi and Evolution 30(12): 2725-2729.

Waugh, J. 2007. DNA barcoding in animal species: progress, potential and pitfalls. Bioessays 29(2): 188-197. 